\title{
Global fungal spore emissions, review and synthesis of literature data
}

\author{
A. Sesartic and T. N. Dallafior \\ ETH Zurich, Institute for Atmospheric and Climate Science, 8092 Zurich, Switzerland
}

Received: 11 October 2010 - Published in Biogeosciences Discuss.: 18 November 2010

Revised: 29 April 2011 - Accepted: 11 May 2011 - Published: 17 May 2011

\begin{abstract}
The present paper summarizes fungal spore emission fluxes in different biomes. A literature study has been conducted and emission fluxes have been calculated based on 35 fungal spore concentration datasets. Biome area data has been derived from the World Resource Institute. Several assumptions and simplifications needed to be adopted while aggregating the data: results from different measurement methods have been treated equally, while diurnal and seasonal cycles have been neglected. Moreover flux data were aggregated to very coarse biome areas due to scarcity of data. Results show number fluxes per square meter and second of 194 for tropical and subtropical forests, 203 for all other forests, 1203 for shrub, 2509 for crop, 8 for tundra, and 165 for grassland. No data were found for land ice. The annual mean global fluxes amount to $1.69 \times 10^{-11} \mathrm{~kg} \mathrm{~m}^{-2} \mathrm{~s}^{-1}$ as the best estimates, and $9.01 \times 10^{-12} \mathrm{~kg} \mathrm{~m}^{-2} \mathrm{~s}^{-1}$ and $3.28 \times 10^{-11} \mathrm{~kg} \mathrm{~m}^{-2} \mathrm{~s}^{-1}$ as the low and high estimate, respectively.
\end{abstract}

\section{Introduction}

Fungal spores are part of the bioaerosol population in our atmosphere which also comprises components such as pollen, bacteria or viruses. Interest in bioaerosols is mainly related to their health effects, agriculture, ice nucleation and cloud droplet activation or atmospheric chemistry (Ariya et al., 2009). In the present study, the focus lies on fungal aerosols.

Measurements of fungal aerosols report average ground level concentrations of around $10000-50000$ spores $^{-3}$, sometimes even exceeding 200000 spores $\mathrm{m}^{-3}$ (Levetin, 1995). This is two orders of magnitude higher than observed

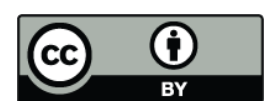

Correspondence to: A. Sesartic (ana.sesartic@env.ethz.ch) peak pollen concentrations (1000-2000 grains $\mathrm{m}^{-3}$ ) (Mandrioli, 1998). Froehlich-Nowoisky et al. (2009) also state that up to $45 \%$ of the coarse particle mass in tropical rainforest air consists of fungal spores. Elbert et al. (2007) found that fungal spores are the main contributor to the bioaerosol mass in the Amazon basin. Simulations conducted by Heald and Spracklen (2009) came to the conclusion that $23 \%$ of all primary emissions of organic aerosol are of fungal origin. Investigations of Bauer et al. (2002b) have shown that " $5.8 \%$ of the organic carbon in the coarse aerosol mode" was due to fungal spores and bacteria. When sampling bioaerosols at the Rothampsted Experimental Station in the south of England, Gregory (1978) found that they mainly consisted of fungal spores; nearly half of a fair weather sample consisted of Cladosporium spores (a mould) and only one percent of all bioaerosols were plant pollen. These findings show that fungal spores are an non-negligible part of the atmospheric aerosol. Fungi are even found in marine habitats where they are important decomposers of plant substrates (Hyde et al., 1998). As marine fungal spore emission observations are lacking so far, this biome has not been further taken account of in this review.

The primary source of fungal aerosols are plants (Burgess, 2002), soil, litter and decaying organic matter (Heald and Spracklen, 2009). Release mechanisms of fungal spores are numerous and vary from species to species (Elbert et al., 2007; Gregory, 1967, 1973; Levetin, 1995; Jones and Harrison, 2004; Madelin, 1994; Hirst, 1953). Generally, release of spores is highly dependent on meteorological factors. Some require rather humid conditions whereas others favour dry and windy conditions for spore release. Several studies have been conducted on the relationship between meteorological factors and spore concentrations. Significant correlations between spore counts and wind speeds could be found (Glikson et al., 1995) as well as a positive correlation of Alternaria spore counts with temperature (Burch and Levetin, 2002).

Published by Copernicus Publications on behalf of the European Geosciences Union. 
Stepalska and Wolek (2009) on the other hand could not find a significant correlation of spore concentrations with weather conditions for most species investigated in their study. It is hence difficult to predict which and how many spores are released according to weather conditions.

As for their transport behaviour, most of the spores do not travel very long distances. As calculations by Gregory (1962) have shown only a fraction of about $10 \%$ of all released fungal spores is transported farther away than $100 \mathrm{~m}$. This fraction is called the "escape fraction". The measured concentrations are a blend of local emissions and advected spores. It is difficult to distinguish between those two groups. A possible distinction criterion might be the size or shape since larger particles are deposited more easily than smaller ones. However, Heald and Spracklen (2009) note that the larger size fraction is less well investigated due to measurement device constraints. The farther away the sampling device is from the spore source, the more is the measured concentration influenced by deposition and other processes. This can lead to devices in immediate proximity to the ground measuring the actually emitted spore numbers, whereas other devices on higher levels might measure the escape fraction only. As most observational data was taken further away from the ground, we assume our estimate to represent the escape fraction.

Wind speed, temperature, atmospheric pressure or precipitation are important conditions determining transport and deposition of the dispersed aerosols (Hirst et al., 1967). There is evidence that fungal spores can also be transported over long distances (Griffin et al., 2006, 2001; Prospero et al., 2005 ) before they are deposited either due to gravity, washout by rain or impaction (Gregory, 1967). Among others, Prospero et al. (2005) found fungal spores originating from the African desert to influence the prevailing fungal spore concentrations on the Virgin Islands in the Caribbean.

Some fungal spores can act as very effective ice nucleators. Lichen were found to nucleate ice at temperatures higher than $-8{ }^{\circ} \mathrm{C}$ and some even at temperatures higher than $-5^{\circ} \mathrm{C}$ (Kieft, 1988). The lichen fungus Rhizoplaca chrysoleuca was even found to be an active ice nucleus at temperatures as high as $-2{ }^{\circ} \mathrm{C}$ (Kieft, 1988; Kieft and Ruscetti, 1990). To date, only a few fungus species have been found to be active ice nucleators: besides the above mentioned lichen these are Fusarium avenaceum and Fusarium acuminatum (Pouleur et al., 1992). The ice nucleating activity of $F$. avenaceum is comparable to that of the bacterium Pseudomonas sp. (Pouleur et al., 1992). In contrast to those findings is the recent research by Iannone et al. (2011) that showed poor ice nucleation ability of Cladosporium spores, with immersion freezing starting at $-28.5^{\circ} \mathrm{C}$. This might be due to the spores being coated with hydrophobic proteins that are widespread in filamentous fungi such as Cladosporium sp. Additionally, fungal aerosols are likely to be effective cloud condensation nuclei, but data on behalf of this is still scarce.
Recent field measurements have highlighted the importance of bioaerosols as ice nucleators in the atmosphere, e.g. Pratt et al. (2009) and Prenni (2009). Relying on the above evidence, there is probably a link between meteorological conditions and fungal spores as well. On the one hand, fungal spores acting as ice nuclei might influence cloud and precipitation formation process, as has already been proposed by Morris et al. (2004) in general for biological ice nuclei. On the other hand, changes in climatic conditions also alter the meteorological situation on a smaller time scale which in turn might influence fungal spore release as well as transport according to the respective release mechanism. These possible interactions with the weather and climate system as well as the fact that fungi are one of the major contributors to global bioaerosols makes it crucial to gain more knowledge about the circumstances and amounts in which they are emitted as well as their transport behaviour. Many studies have already focused on sampling of fungal spores in order to estimate their concentration in the atmosphere. However, a standardised procedure in order to do so is still missing which leads to very heterogeneous and hardly comparable results.

The goal of this paper is to review the available literature data on fungal spores and estimate global fungal spore emissions by biome area. Available literature is reviewed and data provided used to derive the respective fungal spore fluxes for major ecoregions. Moreover, measurement methods are reviewed and discussed.

\section{Data and methods}

A review of available fungal spore concentration data has been undertaken. Fungal spore concentration data have been assigned to an ecosystem and converted to surface number and mass fluxes. More than 150 studies have been reviewed of which 35 have been found to contain data relevant for this study, and thus were taken into account for flux calculations. Exclusion criteria were a lack of information about measurement sites, biomes, measurement period, only absolute spore counts considered instead of concentrations, and petri dish samplings.

The biome areas by Olson et al. (2001) have been used for ecosystem classification. But since data points were not sufficiently dense, broader definitions of the respective biomes had to be taken. These ecoregions covered tropical and nontropical forests, shrub, grass, crop, tundra and land ice (data based on (World Resource Institute, 2003a,b)). Attribution of the respective ecoregions by Olson et al. (2001) to the biome areas used here has been done according to Table 1 . The biome "crop" was used when the studies mentioned close proximity to agriculture land. Effects of urban environments were not taken into account. Biome area data has been derived from World Resource Institute (2003a,b). Figure 1 shows the global distribution of available measurement data. 
Table 1. Attribution of ecosystems by (Olson et al., 2001) to the respective biome areas

\begin{tabular}{lll}
\hline Ecoregion after Olson et al. (2001) & Biome & Area $\left[\mathrm{km}^{-2}\right]$ \\
\hline Tropical and Subtropical Moist Broadleaf Forests & $\begin{array}{l}\text { Tropical forest } \\
\text { Tropical forest }\end{array}$ & \multirow{2}{*}{14076491} \\
Tropical and Subtropical Dry Broadleaf Forests & $\begin{array}{l}\text { Tropical forest } \\
\text { Tropical and Subtropical Coniferous Forests }\end{array}$ & \multirow{2}{*}{ Forest } \\
Temperate Broadleaf and Mixed Forests & Forest & \\
Boreal Forests/Taiga & Shrub & \\
Tropical and Subtropical Grasslands, Savannahs, and Shrubland & Shrub & \\
Temperate Grasslands, Savannahs, and Shrubland & Shrub & 23343164 \\
Flooded Grasslands and Savannahs & Shrub & \\
Montane Grasslands and Shrubland & Shrub & \\
Mediterranean Forests, Woodlands, and Shrubs & Grassland & 10542721 \\
Desert and Xeric Shrublands & Crop & 15206323 \\
Crop & Tundra & 4630000 \\
Tundra & & \\
\hline
\end{tabular}

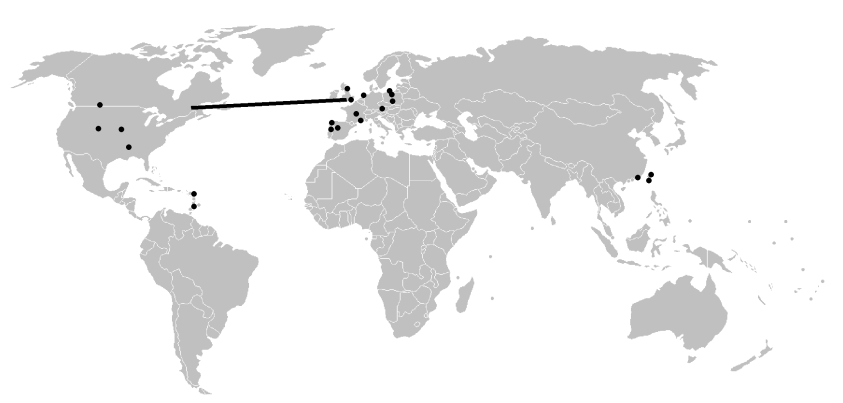

Fig. 1. Global distribution of locations where fungal spore emissions have been measured. The transect over the ocean denotes ship measurements.

Fluxes have been calculated based on fungal spore concentrations, the height $(\Delta z)$ at which the spore concentration has been measured and the time $(\Delta t)$ necessary for an uniform mixing of the atmospheric layer between ground and the height of the measurement:

$F_{\text {fungal spore }}=\frac{\text { number concentration } \times \text { spore mass } \times \Delta z}{\Delta t}$

$\Delta z$ has been assumed to be $10 \mathrm{~m}$. This is the average sampling height at which fungal spore concentrations have been measured, considering that sometimes samples have been taken at ground level, sometimes above tree level or on top of buildings. The height of $10 \mathrm{~m}$ for $\Delta z$ is justified because it is at the top of the Prandtl layer in which fluxes between the ground and the atmosphere are constant with height (Colombe Siegenthaler-LeDrian and Tanja Stanelle, personal communication, 2011). We assume the concentration measured at this level to be in a steady state between spore emissions and dry deposition.

As the density of fungal spores is slightly lower than that of air, they are lifted with thermals and their dry deposition can be neglected for this offline calculation. This is supported by a terminal velocity of $v=6.12 \times 10^{-7} \mathrm{~ms}^{-1}$ which can be derived assuming a fungal spore diameter of $10 \mu \mathrm{m}$ and a density of $1 \mathrm{kgm}^{-3}$.

The timescale for turbulent diffusion in the $10 \mathrm{~m}$ layer can be obtained from

$\Delta t=\frac{(\Delta z)^{2}}{2 \times K_{\text {turb }}}=50 \mathrm{~s}$

with $\Delta z=10 \mathrm{~m}$ and turbulence diffusion coefficient $K_{\text {turb }}=10^{5} \mathrm{~cm}^{-2} \mathrm{~s}^{-1}$ (Jacob, 1999).

Alternative approaches to calculate fungus fluxes have been derived for instance by Heald and Spracklen (2009) and used by Hoose et al. (2010):

$F_{\text {fungal spores }}=500 \mathrm{~m}^{-2} \mathrm{~s}^{-1} \frac{\mathrm{LAI}}{5} \frac{q}{1.5 \times 10^{-2} \mathrm{kgkg}^{-1}}$

where LAI is the leaf area index, a measure for the leaf area per surface area and $q$ is the specific humidity. The second of the two flux calculation methods has not been used since the LAI is not necessarily a good measure of spore emissions, as it would create a bias towards too low fungal spore fluxes in regions where the LAI is very low, such as grasslands.

Spore masses have been derived by Winiwarter et al. (2009): Assuming an average carbon content of $13 \mathrm{pg} C$ per spore (Bauer et al., 2002a,b), a water content of $20 \%$ per spore and $50 \% \mathrm{C}$ per dry mass (Sedlbauer and Krus, 2001) they determined a fungal spore mass of $33 \mathrm{pg}$. Calculations by Elbert et al. (2007) resulted in remarkably higher values: assuming a mass density of about $1 \mathrm{gcm}^{-3}$ and a volume equivalent diameter of about $7 \mu \mathrm{m}$, the average mass of wet spore discharged by Ascomycota would be around $200 \mathrm{pg}$. Assuming the same density for Basidiomycota, Elbert et al. (2007) derived a mass of $65 \mathrm{pg}$.

For calculation of mass fluxes in this paper, the average mass of $33 \mathrm{pg}$ per spore has been assumed. The number and 
Table 2. Number fluxes of fungal spores per square metre of biome and second $\left[\mathrm{m}^{-2} \mathrm{~s}^{-1}\right]$.

\begin{tabular}{llll}
\hline Biome & low estimate & best estimate & high estimate \\
\hline Tropical forest & 93 & 194 & 458 \\
Forest & 31 & 214 & 387 \\
Shrub & 37 & 1203 & 3472 \\
Grassland & 14 & 165 & 1111 \\
Crop & 2469 & 2509 & 2549 \\
Tundra & 1 & 8 & 15 \\
\hline
\end{tabular}

mass fluxes are listed once per second and once per second and square meter of the specific biome. Global averages are derived by taking the mean of the respective values for each biome area.

The following assumptions have been made for the flux calculations:

- Seasonal or daily cycles do not influence the measured spore concentrations.

- There is no difference between colony forming units (CFU) and total counts.

- Due to data scarcity the measurements taken at specific ecosystems were summarised in broader categories (cf. Table 1).

- Similar assumptions have been made for the other biome regions.

Best estimates have been calculated from all average spore concentration data available. Lau et al. (2006) are the only researchers that have expressed their data with the geometric mean instead of the arithmetic mean. Since the difference between the geometric mean and the arithmetic mean are small, they have been treated in the same manner. It should be noted that for the low and high estimates of crop emissions, only one measurement result was available. Where no average concentrations were provided, the average between the maximum and minimum spore concentrations (if available) has been taken instead. The high and low estimates are the averages of all minimum and maximum spore counts (where available). In the optimum case, total spore counts were provided covering all identifiable species. However, in some studies, only certain genera were investigated. Where spore counts had been split according to species, the sum over all has been taken in order to get as close as possible to the number of total counts.

Table 2 shows the aggregated number fluxes of fungal spores per square metre of biome and second, while Table 3 shows the respective mass fluxes in $\mathrm{kg}$ per square metre and second. The biome area with the largest fungal spore flux is crop followed by shrub, tropical and non-tropical forest, grassland and tundra in descending order. This can also be
Table 3. Mass fluxes of fungal spores per square metre of biome and second $\left[\mathrm{kgm}^{-2} \mathrm{~s}^{-1}\right]$.

\begin{tabular}{llll}
\hline Biome & low estimate & best estimate & high estimate \\
\hline Tropical forest & $3.06 \times 10^{-12}$ & $6.40 \times 10^{-12}$ & $1.51 \times 10^{-11}$ \\
Forest & $1.02 \times 10^{-12}$ & $7.08 \times 10^{-12}$ & $1.28 \times 10^{-11}$ \\
Shrub & $1.22 \times 10^{-12}$ & $3.97 \times 10^{-11}$ & $1.15 \times 10^{-10}$ \\
Grassland & $4.65 \times 10^{-13}$ & $5.44 \times 10^{-12}$ & $3.67 \times 10^{-11}$ \\
Crop & $8.15 \times 10^{-11}$ & $8.28 \times 10^{-11}$ & $8.41 \times 10^{-11}$ \\
Tundra & $4.49 \times 10^{-14}$ & $2.62 \times 10^{-13}$ & $4.79 \times 10^{-13}$ \\
\hline
\end{tabular}

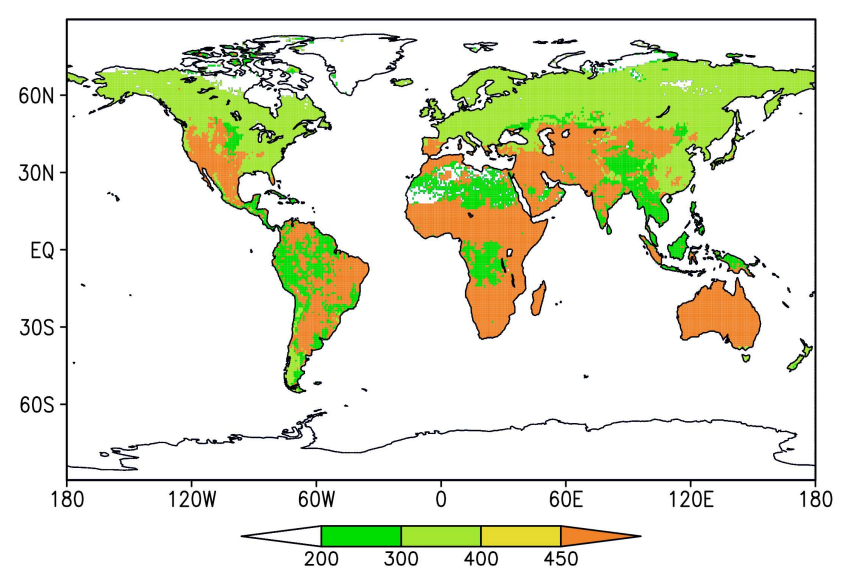

Fig. 2. Best estimate weighted annual mean fungal spore number flux in $\mathrm{m}^{-2} \mathrm{~s}^{-1}$.

seen in Fig. 2, showing the fungal number flux, which was produced by combining the best estimates of reviewed fungal spore data with the plant functional types from the JSBACH dynamic vegetation model (Raddatz et al., 2007).

As for the prevalence of different spore genera, most of the studies agree that Cladosporium make up a very dominant part of the fungal spore air spora, e.g. Sakiyan and Inceoglu (2003); Mallo et al. (2010). Other species such as Alternaria, Aspergillus, Ganoderma, Agaricus, Coprinus, Leptosphaeria or smuts and rusts have been considered as important constituents, but usually showed much lower concentrations than Cladosporium (e.g. Sakiyan and Inceoglu, 2003; Mallo et al., 2010). Based on literature studies, Goncalvez et al. (2010) concluded that Asperigllus, Alternaria and Penicillium were predominant in hot climates, whereas Cladosporium spores were found to be most abundant in temperate climatic regimes.

\subsection{Review of measurement methods}

The simplest method to measure airborne fungal spores is to expose sticky surfaces or petri dishes and then count either all detectable fungal spores or, in the case of petri dishes, the colony forming units (CFU). This method has for instance been used by Bhati and Gaur (1979) or 
Abu-Dieyeh et al. (2010). The obtained sample results are useful in order to get a qualitative impression of the composition of the prevailing air spora. However, Gregory (1952) pointed out that these data imply the "tacit assumption that the relation between the number of particles suspended in the air flowing over the surface and the number deposited on the surface is known". Gregory (1952) further argue that these simple rules would only apply for still air. According to the authors of the study, the efficiency of a sticky surface to collect fungal spores rather varies with wind speed and subsequently number concentrations per unit volume are difficult to obtain. Gregory (1952) note, that a good sampling device draws in "a known volume of air without altering its spore content, removes all particles over the $2-100 \mu \mathrm{m}$ size range, and leaves them in a form in which they can be examined, counted and classified".

Hirst (1952) described the features a measurement device should have in order to give useful results: Besides the ability of assessing the spore concentration per unit volume of air, it should also be possible to measure in distinct time intervals to better correlate concentrations with meteorological conditions. He designed a spore trap that was able to suck in air and subsequently impact the contained spores on a sticky surface. The principle of suction increases, as Hirst (1952) argues, the efficiency of filtration and impaction. However, he also found that this does not guarantee for the air masses entering the trap being representative of the actual spore load (collection efficiency). To counteract this problem, Hirst (1952) proposed that air should be sampled isokinetically and that the orifice should always be directed into the airstream. In order to get a distinction in time, a sticky slide is moved slowly past the orifice (Hirst, 1952). As suction rates are constant, trapping efficiencies change with wind speeds (Hirst, 1953).

Recent methods take advantage of biochemical properties of fungal spores. Elbert et al. (2007) for instance use mannitol (a component of fungal cell membranes) as a fungal biomarker to determine their prevalence in air masses. Bauer et al. (2008) rely on other biochemical tracers such as mannitol or arabitol to measure the fungal spore content in the precipitation.

A review of the available studies of spore concentrations showed that the measurement methods applied were diverse. As outlined above, data from measurements with petri dishes have not been included in the flux calculations for this paper due to the above named reasons. The trapping efficiency of petri dishes is no higher than $5 \%$ which is remarkably lower than the $80 \%$ trapping efficiency of a Hirst trap (Davies et al., 1963, citing Gregory and Stedman, 1953).

Among the data sets used for calculations, many of the researchers relied on the Hirst-type spore trap as described above, e.g. (Davies et al., 1963; Hamilton, 1959; RodríguezRajo et al., 2005; Oliveira et al., 2009; Mallo et al., 2010; Levetin and Dorsey, 2006; Herrero et al., 2006; Wu et al., 2004; Stepalska and Wolek, 2009; Kasprzyk and Worek,
2006; Sakiyan and Inceoglu, 2003). Among these, mostly models from Lanzoni (VPPS 2000) (Lanzoni, 2010) or Burkard (Burkard Scientific, 2000) were used. Others relied on Filterhousings containing $2 \mu \mathrm{m}$ filter membranes, e.g. Prospero et al. (2005); Griffin et al. (2001, 2003, 2007), for their measurement. Another device sometimes used was the May Cascade Impactor (May, 1945). However, this device was found to have a considerably lower trapping efficiency for small spores than the Volumetric Spore Trap (Hirst, 1953). Only a few of the studies monitored the fungal spore content in cloud droplets or precipitation (Amato et al., 2007; Bauer et al., 2002a) and some other measurement devices and methods apart from those named above have been used as well (for detailed information on measurement methods see Table A1 in the appendix).

The measurement duration varied from a few minutes to continuous measurements seven days a week (especially applied for the Hirst-type spore traps). Also the time span over the year varied from study to study: some only measured on one single day, e.g. Côté et al. (2008), others even over several years continuously, e.g. Mallo et al. (2010).

Besides the heterogeneity of the used measurement devices also the airflow varied from $1.91 \mathrm{~min}^{-1}$ (Griffin et al., 2001) up to $1.13 \mathrm{~m}^{3} \mathrm{~min}^{-1}$ (Lau et al., 2006). An airflow of $101 \mathrm{~min}^{-1}$ seems to be the most commonly used value for such measurements. Moreover it was difficult to retrieve the airflow rates from all studies. The correct choice of airflow is an important factor for spore measurements since measurements that are not conducted isokinetically can lead to remarkable biases in spore counts.

Furthermore the height at which the devices had been installed was not the same in the respective studies. Some used air samples in heights up to several kilometres, whereas other conducted ground-based measurements in heights from $2 \mathrm{~m}$ up to $50 \mathrm{~m}$. When considering spore dispersal from a boundary layer meteorological point of view, the choice of the measurement height might be crucial since it decides on whether measurements are taken within or outside the turbulent layer.

The situation is alike for the different impaction media chosen: whereas those using the Lanzoni Hirst-type spore trap rely on so-called Melinex tape which is mounted after spore collection with glycerol jelly, others use different surfaces. The same situation can be found when it comes to the use of nutrient media for growth of the trapped fungal spores (viable counts). Some rely on R2A agar, others on YM (yeast-morphology) agar, others on Sabouraud's medium for fungi or malt-agar extract, etc. The possibilities for fungus incubation for viable counts are numerous. Incubation times vary from two days up to two weeks and longer and so do also the incubation temperatures applied. Moreover, counting methods are not the same in all studies. Some use optical methods such as microscopy or macroscopy with different magnifications (ranging from $40 x-1000 x$ ) while others use Polymerase Chain Reaction (PCR) to determine genera and species from their genome. As for the nutrient medium 
chosen, both Abdel-Hafez et al. (1985) and Abdel-Hafez et al. (1986) conclude that the choice of nutrient medium had an influence on the prevalence of respective species counted.

To sum up, the measurement methods differ at many stages of the measurement and counting process: The counting device, the airflow chosen, the placement of the sampling device, the sticky medium, the nutrient medium (for viable counts), the incubation duration and the counting method. It is crucial to introduce a convention on how to exactly measure fungal spores in the atmosphere in order to prevent biases due to different measurement methods and to increase comparability of results.

\subsection{CFU vs. total spore count}

Not all studies have investigated both the total count of all spores available and the counts of viable spores called colony forming units (CFU) after incubation. However, this would be an important source of information on what share of the atmospheric fungal spora is viable and which is not (Gregory, 1967). In very few of the studies, both the viable and total counts of spores have been investigated, e.g. Lau et al. (2006); Pady and Kapica (1955); Griffin et al. (2001); Bauer et al. (2002a). All other studies either published total spores or only CFUs. In order to assess their activity as CCN or IN it is not relevant whether they are alive or not. The important feature is the shape and presence of the active proteins which actually act as nuclei (Kieft and Ruscetti, 1990). Therefore, it is not the viability of the fungal spore that affects its IN activity, but whether the ice nucleation active proteins on its surface are denatured or not. If the protein conformation is intact, it can trigger the ice nucleation, regardless of the cell's viability. However, it is important that the cell has been alive at one point in order to produce the ice nucleation proteins in the first place. Therefore it is all the more important to evaluate total counts instead of only viable counts in order to include all possible IN present on the spore surface.

Pady and Kapica (1955) found that silicone slides exposed in a slit sampler revealed spore counts a manifold higher than those of plates exposed at the same time where CFUs had been counted. This could be explained by a remarkable bias between viable and total spore counts. Gregory (1967) found that viability of Alternaria spores averaged at $80 \%$ and that of Cladosporium spores at $42 \%$ with viability decreasing at midday. Hence, viability varies from species to species. Other sources report Cladosporium viability to be on average at $62 \%$ (Pady and Gregory, 1963). Experiments by Harvey (1967) investigated viability of Cladosporium and came to the conclusion that single spores germinate more readily than clumps of spores. Moreover they also found a diurnal cycle in germination that reached maximum values between 10:00 UTC and 18:00 UTC and minimum values at 02:00 UTC. However, the authors also state that this cyclicality of viability is in disagreement with the findings by Pathak and Pady (1965). Bauer et al. (2002a) estimated the total vi-
Table 4. Weighted average number $\left[\mathrm{m}^{-2} \mathrm{~s}^{-1}\right]$ and mass $\left[\mathrm{kgm}^{-2} \mathrm{~s}^{-1}\right]$ fluxes of fungal spore emissions over land.

\begin{tabular}{llll}
\hline & low estimate & best estimate & high estimate \\
\hline number flux & 273 & 513 & 995 \\
mass flux & $9.01 \times 10^{-12}$ & $1.69 \times 10^{-11}$ & $3.28 \times 10^{-11}$ \\
\hline
\end{tabular}

ability of the sampled bacteria and fungi to be around $87 \%$ using the condition of the cell wall as a criterion to determine viability. Analysis of snow samples then showed that the cultivable part of fungi amounted only up to $0.7 \%$ (Bauer et al., 2002a). This seems a very low number, but it is sensible considering the fact that these spores already had to survive very harsh conditions within the ice crystals or even during precipitation formation processes. Fisar et al. (1990) compared two counting methods, CFUs and direct counts (Fluorescence technique; see respective paper for detailed description of this method) and came to the conclusion that the difference between CFUs and direct counts for both, bacteria and yeasts, is not only considerable but also highly variable. The authors added that seasonal trends in these discrepancies were not detected.

The information provided in the above section is strong evidence for the fact that CFU counts and total spore counts are not equal at all. Due to the scarcity of studies including both viable and total counts, values for CFUs and total spore counts have been treated equally in this paper knowing that the two counting methods show remarkable differences in resulting counts.

\section{Discussion}

The fungal spore fluxes for the respective biome areas are in the expected orders of magnitude. The more a biome region is vegetated, the higher are the fungal spore emissions (cf. Table 2 and Fig. 2). This makes sense considering the fact that plants are the largest source of fungal bioaerosol. This reasoning is also supported by Heald and Spracklen (2009), although their fungal spore flux calculations are based on the leaf area index (LAI) which might result in a bias towards too low emissions for biomes with lower LAI as already pointed out in Sect. 2.

Unfortunately, no useful data in land ice areas were found so that emissions are not available for this ecoregion. It would nonetheless be worth investigating these regions as well. Lichen soredia (i.e. the reproductive structure of lichen) have been reported to be most abundant in maritime Antarctica (Henderson-Begg et al., 2009, citing Marshall 1996). Considering the fact that lichen have been found to be effective ice nuclei, it is probable that lichen in these ecoregions do have an influence on cloud microphysical processes as well as precipitation formation. A number of studies mainly 
focused on species such as Cladosporium, Aspergillus or Alternaria. This is mainly because these fungi can cause allergies (Goncalvez et al., 2010, citing Vijay 2005 and Shen 2007).

Heald and Spracklen (2009) conducted an estimate of fungal spore emissions based on mannitol concentrations (a biotracer for fungi) using the GEOS-chem chemical transport model (see respective paper for detailed information). Two major differences between the respective results can be seen in the tropical regions. Whereas Heald and Spracklen (2009) found highest values in the Amazon and tropical African region, the present study does not reveal maximum values in these regions. Moreover, mass fluxes found by Heald and Spracklen (2009) are with $5.96 \times 10^{-12} \mathrm{~kg} \mathrm{~m}^{-2} \mathrm{~s}^{-1}$ an order of magnitude lower than those presented here (cf. Table 4). (Winiwarter et al., 2009), who calculated global average fungal spore emissions of $5.71 \times 10^{-13} \mathrm{kgm}^{-2} \mathrm{~s}^{-1}$ came to values two orders of magnitude smaller. Nevertheless, the values presented here $\left(1.69 \times 10^{-11} \mathrm{kgm}^{-2} \mathrm{~s}^{-1}\right.$, for best estimate cf. Table 4) are in agreement with the study by Elbert et al. (2007) that presents a fungal spore mass flux of $2.26 \times 10^{-11} \mathrm{kgm}^{-2} \mathrm{~s}^{-1}$.

The lower values found in tropical regions can partly be explained by the fact that fungal spore data for tropical forests have been aggregated up to one biome area irrespective of forest type. Both methods are prone to biases and errors. The downsides of the present method will be outlined in Sect. 3.1. However, it is also likely that the results by Heald and Spracklen (2009) are based on different asumptions. As outlined in Sect. 1 fungal spore composition and size can be very heterogeneous and variable. Nevertheless, the approach of Heald and Spracklen (2009) is promising as seasonality and meteorological influences have been taken into account.

Probably the measurements of actual spore concentrations as well as the measurements of biological tracer substances to derive fungal spore fluxes have to be seen in a complementary way. Concentration measurements on the one hand yield absolute counts of all fungal spores, but comprise measurement issues outlined in previous sections as well as some problems with the identification of fungal spores. As for the biochemical tracer method, these problems are not encountered, but more knowledge needs to be gained in terms of chemical composition of primary biological aerosols as to better describe them and hence yield more accurate results. Therefore it is useful to intercompare the two approaches in order to determine possible sources of error and strengthen hypotheses where agreement is achieved.

\subsection{Sources of error}

As mentioned above, the results of this study have to be taken with caution. The density of measurement points was not sufficient to take into account all ecosystems and therefore only a very coarse distinction into the here presented biome areas could be made. This also implies that for example a deciduous broadleaf forest is considered to emit the same amount and kind of spores as a coniferous forest in higher latitudes. This of course does not make sense from a biological point of view. Moreover, the seasonal and diurnal cycles which clearly have been detected (see Sect. 2) could not be extended to all biomes and fungal species due to scarcity of data. The fact that the difference between CFUs and total counts is not considered clearly must bias the results especially since only very little information is available on what share of fungal spores are viable.

The present data have been calculated on the basis of many simplifications and assumptions that had to be made due to the scarcity of data. As outlined in Sect. 2, also measurement methods showed high heterogeneity which can clearly be regarded as a source of bias in the present dataset. Nevertheless it is a step towards enumerating fungal spore concentrations and fluxes on a global basis. We hope that our review will motivate further observations of fungal spore emissions, which might ultimately lead to an improved global database.

\subsection{Outlook}

In order to minimise the above named sources of error, measurement methods need to be standardised in order to allow for better comparability. Furthermore, results should always comprise both CFU and viable count data. To allow for a finer resolution of flux data, data points should be distributed more densely and represent a larger set of investigated ecosystems. In order to account for seasonal and daily cycles, measurements should be continuous over periods at least lasting a full year.

Since investigation of bioaerosols in general is highly interesting due to their possible influence on cloud microphysical processes, further research would be needed to learn more about the potential of fungal spores to act as CCN or IN. Moreover, lichen which have been reported to be effective IN should be investigated better since they are more abundant in the atmosphere than bacteria (Henderson-Begg et al., 2009). Additionally, data should not only focus on allergy causing fungi, but also on those spores which presumably influence atmospheric processes. It would therefore also make sense to investigate concentrations of IN active spores such as Fusarium in order to get a broader picture of what share of all fungal spores is actually involved in ice crystal formation processes.

\section{Conclusions}

The present study has reviewed data and information available on fungal spore concentrations and derived fungal spore emissions. As outlined above, data quality in general is rather poor due to the heterogeneity of the applied measurement methods as well as the quality of the measurements themselves. A standardized measurement method 
Table A1. Sources used for fungal spore flux calculations and details about their measurement procedure. Most samplings considered the total spore counts, those that considered only certain genera are indicated by the footnotes.

\begin{tabular}{|c|c|c|c|}
\hline Source & Sampling Device & Airflow & Sample Period/Number of Samplings \\
\hline Amato et al. (2005) & Single stage cloud collectors & $\mathrm{n} / \mathrm{a}$ & 2 Samplings \\
\hline Amato et al. (2007) & Sterilised cloud droplet impactor & $\mathrm{n} / \mathrm{a}$ & 7 cloud events \\
\hline Bauer et al. (2002a) & Active cloud water sampler & $\mathrm{n} / \mathrm{a}$ & 3 cloud events, 8 samplings \\
\hline Beaumont et al. (1985) & Andersen Sampler model 0101 & $28.31 \mathrm{~min}^{-1}$ & 1981-1983/weekly, 3 samplings per day \\
\hline Burch and Levetin (2002) & Burkart volumetric spore trap & $\mathrm{n} / \mathrm{a}$ & four days in September \\
\hline Côté et al. (2008) & & $12.51 \mathrm{~min}^{-1}$ & $6.5 \mathrm{~h} /$ one sampling \\
\hline Davies et al. (1963) & Hirst-type spore trap & $101 \min ^{-1}$ & $\mathrm{n} / \mathrm{a}$ \\
\hline Herrero et al. (2006) & Hirst-type spore trap (Burkart) & $\mathrm{n} / \mathrm{a}$ & year 2003/continuous samplings \\
\hline DiGiorgio et al. (1996) & Hirst-type spore trap (Burkart) & $401 \min ^{-1}$ & one year/2 samplings a week \\
\hline Elbert et al. (2007) & Rotating impactor, isokinetic jet impactor & $\mathrm{n} / \mathrm{a}$ & 2001/continuous measurements \\
\hline Fisar et al. (1990) & Single stage large-volume impactor & $421 \min ^{-1}$ & 50-2001 per sample, i.e. a few minutes \\
\hline Glikson et al. (1995) & Teflon filters for PM10 & $\mathrm{n} / \mathrm{a}$ & 4-8 1992/daily samplings \\
\hline Gregory (1952) & May cascade impactor & $101 \min ^{-1}$ & $24 \mathrm{~h}$ \\
\hline Griffin et al. (2001) & Filter samples & $9.31 \mathrm{~min}^{-1}$ & 18-28 July 20005 samplings \\
\hline Griffin et al. (2003) & Filter membrane & $6.5-28.41 \mathrm{~min}^{-1}$ & 18 July $2000-8$ August 2001 \\
\hline Griffin et al. (2006) & Filter membrane & $1.9-17.41 \mathrm{~min}^{-1}$ & 06:30-18:45 UTC/2-3 air samplings \\
\hline Griffin et al. (2007) & Membrane Filtration & $\mathrm{n} / \mathrm{a}$ & 3-10 2002/continuous samplings \\
\hline Griffin (2007) & Data taken from multiple sources & $\mathrm{n} / \mathrm{a}$ & $\mathrm{n} / \mathrm{a}$ \\
\hline Hamilton (1959) & Hirst-type spore trap & $101 \min ^{-1}$ & 5-9 $1954 / 15$ min per day \\
\hline Ho et al. (2005) & Hirst-type spore trap & $101 \min ^{-1}$ & continuous from 1993 to 1996 \\
\hline Kasprzyk and Worek (2006) & Hirst-type spore trap (Lanzoni) & $101 \min ^{-1}$ & one year/continuous samplings \\
\hline Kellogg et al. (2004) & in-house designed system & $101 \min ^{-1}$ & $\mathrm{n} / \mathrm{a}$ \\
\hline Lau et al. (2006) & Graseby GMWT 2200 & $1.13 \mathrm{~m}^{3} \mathrm{~min}^{-1}$ & 8-12 2002/weekly samples (72 h) \\
\hline Levetin and Dorsey (2006) & Hirst-type spore trap (Burkart) & $\mathrm{n} / \mathrm{a}$ & 2002/daily samplings \\
\hline Mallo et al. (2010) & Hirst-type spore trap (Lanzoni) & $101 \min ^{-1}$ & 1998-2001 continuous samplings \\
\hline Marks et al. (2001) & Sartorius MD-8 air filtration unit & $0.5-1 \mathrm{~m}^{3}$ & 2-5 July 97 and 2-14 98 \\
\hline Oliveira et al. (2009) & Hirst-type volumetric spore trap & $101 \min ^{-1}$ & 2005-2007/continuous samplings \\
\hline Pady and Kapica (1955) & Bourdillong slit sampler and McGill GE & $28.31 \mathrm{~min}^{-1}$ & 2 sampling flights Montréal-London \\
\hline Prospero et al. (2005) & Filter Samples & $101 \min ^{-1}$ & 1996-1997/continuous samplings \\
\hline Rodríguez-Rajo et al. (2005) * & Hirst-type spore trap (Lanzoni) & $101 \min ^{-1}$ & whole year/continuous samplings \\
\hline Sabariego et al. (2000) & Hirst-type spore trap (Burkart) & $101 \min ^{-1}$ & whole year/continuous samplings \\
\hline Sakiyan and Inceoglu (2003) ${ }^{\dagger}$ & Hirst-type spore trap (Burkart) & $101 \min ^{-1}$ & whole year/continuous samplings \\
\hline Simeray et al. (1993) & S.A.S. Sampler & $0.15 \mathrm{~m}^{3}$ & 1989-1990, 100 s per sample/once a week \\
\hline Stepalska and Wolek (2009) $\ddagger$ & Hirst-type spore trap & $101 \min ^{-1}$ & Daily average concentrations 1997-1999 \\
\hline Winiwarter et al. (2009) & Data taken from multiple sources & $\mathrm{n} / \mathrm{a}$ & $\mathrm{n} / \mathrm{a}$ \\
\hline Wu et al. (2004) & Hirst-type spore trap (Burkart) & $101 \min ^{-1}$ & 12 2000-04 2001/continuous sampling \\
\hline Wu et al. (2007) & Portable air samplers for agar plates & $201 \min ^{-1}$ & $032003-122004,2 \mathrm{~min} / \mathrm{sample} / 2 \mathrm{x}$ monthly \\
\hline
\end{tabular}

* Considered species: Cladosporium sp. and Alternaria sp.

$\dagger$ Considered species: Cladosporium sp. and Alternaria sp.

¥ Considered species: Alternaria sp., Botrytis sp., Cladosporium sp., Didymella sp., and Ganoderma sp.

would be of help in order to minimize measurement biases and allow for better intercomparability of measurements. The resulting global emission flux of fungal bioaerosol of $1.69 \times 10^{-11} \mathrm{~kg} \mathrm{~m}^{-2} \mathrm{~s}^{-1}$ was proven to be in agreement with previous studies. Despite manifold sources of error, the calculated fluxes can be considered as a good first result. This could provide a basis for further research on fungal spore emissions depending on biome area. The resulting fluxes are useful in order to evaluate the impact of global fungal aerosol on weather and climate.

\section{Appendix A}

\section{Overview of measurement methods and observational data}

The following tables comprise information on measurement methods employed by the respective studies (see Table A1) as well as all the values used for flux calculations (see Table A2). Multiple values for the same source can occur in case multiple measurements over different intervals of time had been undertaken or different sites had been chosen for measurement. These cases were treated as single measurement points. 
Table A2. Data used as input for fungal spore flux calculations; average, minimum and maximum number concentrations and number fluxes of fungal spores. The data were always rounded to a whole number. The column CFU (Culture Forming Units) counts denotes if a culture based technique was used for the analysis (yes), if it was a culture-independent technique (no), or if both methods were used.

\begin{tabular}{|c|c|c|c|c|c|c|c|c|}
\hline Source & Ecosystem & $\begin{array}{l}\text { Average conc. } \\
{\left[\mathrm{m}^{-3}\right]}\end{array}$ & $\begin{array}{l}\text { Min conc. } \\
{\left[\mathrm{m}^{-3}\right]}\end{array}$ & $\begin{array}{l}\text { Max. conc. } \\
{\left[\mathrm{m}^{-3}\right]}\end{array}$ & $\begin{array}{l}\text { Average flux } \\
{\left[\mathrm{m}^{-2} \mathrm{~s}^{-1}\right]}\end{array}$ & $\begin{array}{l}\text { Min flux } \\
{\left[\mathrm{m}^{-2} \mathrm{~s}^{-1}\right]}\end{array}$ & $\begin{array}{l}\text { Max flux } \\
{\left[\mathrm{m}^{-2} \mathrm{~s}^{-1}\right]}\end{array}$ & CFU counts \\
\hline Amato et al. (2005) & Forest & 222 & 53 & 390 & 44 & 11 & 78 & yes \\
\hline Bauer et al. (2002a) & Forest & 2200 & 340 & 5000 & 440 & 68 & 1000 & no \\
\hline Bauer et al. (2002a) & Forest & 1200 & 170 & 3200 & 240 & 34 & 640 & no \\
\hline Bauer et al. (2002a) & Forest & 346 & 49 & 863 & 69 & 10 & 173 & no \\
\hline Beaumont et al. (1985) & Forest & 258 & $\mathrm{n} / \mathrm{a}$ & $\mathrm{n} / \mathrm{a}$ & 52 & $\mathrm{n} / \mathrm{a}$ & $\mathrm{n} / \mathrm{a}$ & yes \\
\hline Côté et al. (2008) & Forest & 615 & 492 & 738 & 123 & 98 & 148 & yes \\
\hline Fisar et al. (1990) & Forest & 17 & $\mathrm{n} / \mathrm{a}$ & $\mathrm{n} / \mathrm{a}$ & 3 & $\mathrm{n} / \mathrm{a}$ & $\mathrm{n} / \mathrm{a}$ & Both methods \\
\hline Gregory (1967) & Forest & $\mathrm{n} / \mathrm{a}$ & $\mathrm{n} / \mathrm{a}$ & 43300 & $\mathrm{n} / \mathrm{a}$ & $\mathrm{n} / \mathrm{a}$ & 8660 & no \\
\hline Gregory (1967) & Forest & 5250 & $\mathrm{n} / \mathrm{a}$ & $\mathrm{n} / \mathrm{a}$ & $\mathrm{n} / \mathrm{a}$ & $\mathrm{n} / \mathrm{a}$ & 1050 & no \\
\hline Gregory (1967) & Forest & $\mathrm{n} / \mathrm{a}$ & 766 & $\mathrm{n} / \mathrm{a}$ & 153 & $\mathrm{n} / \mathrm{a}$ & $\mathrm{n} / \mathrm{a}$ & no \\
\hline Kasprzyk and Worek (2006) & Forest & 2144 & $\mathrm{n} / \mathrm{a}$ & $\mathrm{n} / \mathrm{a}$ & 429 & $\mathrm{n} / \mathrm{a}$ & $\mathrm{n} / \mathrm{a}$ & no \\
\hline Kasprzyk and Worek (2006) & Forest & 2183 & $\mathrm{n} / \mathrm{a}$ & $\mathrm{n} / \mathrm{a}$ & 437 & $\mathrm{n} / \mathrm{a}$ & $\mathrm{n} / \mathrm{a}$ & no \\
\hline Kasprzyk and Worek (2006) & Forest & 2093 & $\mathrm{n} / \mathrm{a}$ & $\mathrm{n} / \mathrm{a}$ & 419 & $\mathrm{n} / \mathrm{a}$ & $\mathrm{n} / \mathrm{a}$ & no \\
\hline Kasprzyk and Worek (2006) & Forest & 2146 & $\mathrm{n} / \mathrm{a}$ & $\mathrm{n} / \mathrm{a}$ & 429 & $\mathrm{n} / \mathrm{a}$ & $\mathrm{n} / \mathrm{a}$ & no \\
\hline Marks et al. (2001) & Forest & 105 & 0 & 1000 & 21 & 0 & 200 & yes \\
\hline Marks et al. (2001) & Forest & 223 & 0 & 600 & 45 & 0 & 120 & yes \\
\hline Marks et al. (2001) & Forest & 26 & 0 & 200 & 5 & 0 & 40 & yes \\
\hline Marks et al. (2001) & Forest & 12 & 0 & 45 & 2 & 0 & 9 & yes \\
\hline Oliveira et al. (2009) & Forest & 531 & $\mathrm{n} / \mathrm{a}$ & 8509 & 106 & $\mathrm{n} / \mathrm{a}$ & 1702 & no \\
\hline Rodríguez-Rajo et al. (2005) & Forest & 564 & $\mathrm{n} / \mathrm{a}$ & $\mathrm{n} / \mathrm{a}$ & 113 & $\mathrm{n} / \mathrm{a}$ & $\mathrm{n} / \mathrm{a}$ & no \\
\hline Winiwarter et al. (2009) & Forest & 49 & $\mathrm{n} / \mathrm{a}$ & $\mathrm{n} / \mathrm{a}$ & 10 & $\mathrm{n} / \mathrm{a}$ & $\mathrm{n} / \mathrm{a}$ & \\
\hline Elbert et al. (2007) & Tropical forest & 12476 & 4764 & 20188 & 2495 & 953 & 4038 & no \\
\hline Griffin et al. (2001) & Tropical forest & 45 & $\mathrm{n} / \mathrm{a}$ & $\mathrm{n} / \mathrm{a}$ & 9 & $\mathrm{n} / \mathrm{a}$ & $\mathrm{n} / \mathrm{a}$ & no \\
\hline Griffin et al. (2003) & Tropical forest & 0 & $\mathrm{n} / \mathrm{a}$ & $\mathrm{n} / \mathrm{a}$ & 0 & $\mathrm{n} / \mathrm{a}$ & $\mathrm{n} / \mathrm{a}$ & yes \\
\hline Griffin et al. (2003) & Tropical forest & 57 & $\mathrm{n} / \mathrm{a}$ & $\mathrm{n} / \mathrm{a}$ & 11 & $\mathrm{n} / \mathrm{a}$ & $\mathrm{n} / \mathrm{a}$ & yes \\
\hline Griffin et al. (2003) & Tropical forest & 9 & 5 & 20 & 2 & 1 & 4 & yes \\
\hline Griffin et al. (2003) & Tropical forest & 12 & 8 & 24 & 2 & 2 & 5 & yes \\
\hline Griffin et al. (2007) & Tropical forest & 1702 & 100 & 8510 & 340 & 20 & 1702 & yes \\
\hline Lau et al. (2006) & Tropical forest & 86 & 18 & 341 & 17 & 4 & 68 & both methods \\
\hline Lau et al. (2006) & Tropical forest & 72 & 30 & 294 & 14 & 6 & 59 & both methods \\
\hline Lau et al. (2006) & Tropical forest & 292 & 7 & 2386 & 58 & 1 & 477 & both methods \\
\hline Lau et al. (2006) & Tropical forest & 247 & 50 & 1540 & 49 & 10 & 308 & both methods \\
\hline Prospero et al. (2005) & Tropical forest & 92 & $\mathrm{n} / \mathrm{a}$ & $\mathrm{n} / \mathrm{a}$ & 18 & $\mathrm{n} / \mathrm{a}$ & $\mathrm{n} / \mathrm{a}$ & yes \\
\hline Prospero et al. (2005) & Tropical forest & 213 & $\mathrm{n} / \mathrm{a}$ & $\mathrm{n} / \mathrm{a}$ & 43 & $\mathrm{n} / \mathrm{a}$ & $\mathrm{n} / \mathrm{a}$ & yes \\
\hline Pady and Kapica (1955) & Tropical forest & 37 & 6 & 67 & 7 & 1 & 13 & both methods \\
\hline Pady and Kapica (1955) & Tropical forest & 230 & 170 & 291 & 46 & 24 & 58 & both methods \\
\hline Pady and Kapica (1955) & Tropical forest & 6 & 6 & 6 & 1 & 1 & 1 & both methods \\
\hline Pady and Kapica (1955) & Tropical forest & 44 & 39 & 49 & 9 & 8 & 10 & both methods \\
\hline Pady and Kapica (1955) & Tropical forest & 16 & $\mathrm{n} / \mathrm{a}$ & $\mathrm{n} / \mathrm{a}$ & 3 & $\mathrm{n} / \mathrm{a}$ & $\mathrm{n} / \mathrm{a}$ & both methods \\
\hline Pady and Kapica (1955) & Tropical forest & 31 & $\mathrm{n} / \mathrm{a}$ & $\mathrm{n} / \mathrm{a}$ & 6 & $\mathrm{n} / \mathrm{a}$ & $\mathrm{n} / \mathrm{a}$ & both methods \\
\hline Wu et al. (2007) & Tropical forest & 2233 & $\mathrm{n} / \mathrm{a}$ & $\mathrm{n} / \mathrm{a}$ & 447 & $\mathrm{n} / \mathrm{a}$ & $\mathrm{n} / \mathrm{a}$ & yes \\
\hline Wu et al. (2007) & Tropical forest & 2278 & $\mathrm{n} / \mathrm{a}$ & $\mathrm{n} / \mathrm{a}$ & 456 & $\mathrm{n} / \mathrm{a}$ & $\mathrm{n} / \mathrm{a}$ & yes \\
\hline Burch and Levetin (2002) & Shrub & 50000 & $\mathrm{n} / \mathrm{a}$ & $\mathrm{n} / \mathrm{a}$ & 10000 & $\mathrm{n} / \mathrm{a}$ & $\mathrm{n} / \mathrm{a}$ & no \\
\hline Herrero et al. (2006) & Shrub & 609 & $\mathrm{n} / \mathrm{a}$ & $\mathrm{n} / \mathrm{a}$ & 122 & $\mathrm{n} / \mathrm{a}$ & $\mathrm{n} / \mathrm{a}$ & no \\
\hline DiGiorgio et al. (1996) & Shrub & 92 & $\mathrm{n} / \mathrm{a}$ & $\mathrm{n} / \mathrm{a}$ & 18 & $\mathrm{n} / \mathrm{a}$ & $\mathrm{n} / \mathrm{a}$ & no \\
\hline DiGiorgio et al. (1996) & Shrub & 46 & $\mathrm{n} / \mathrm{a}$ & $\mathrm{n} / \mathrm{a}$ & 9 & $\mathrm{n} / \mathrm{a}$ & $\mathrm{n} / \mathrm{a}$ & no \\
\hline Griffin et al. (2007) & Shrub & 73 & 31 & 115 & 15 & 6 & 23 & yes \\
\hline Griffin et al. (2007) & Shrub & 25 & 0 & 291 & 5 & 0 & 58 & yes \\
\hline Katial et al. (1997) & Shrub & 409 & $\mathrm{n} / \mathrm{a}$ & $\mathrm{n} / \mathrm{a}$ & 82 & $\mathrm{n} / \mathrm{a}$ & $\mathrm{n} / \mathrm{a}$ & no \\
\hline Pady (1957) & Shrub & 24499 & 837 & 48162 & 4900 & 167 & 9632 & no \\
\hline Pady (1957) & Shrub & 715 & 170 & 1261 & 143 & 34 & 252 & no \\
\hline Levetin and Dorsey (2006) & Shrub & 24121 & 53 & 48188 & 4824 & 11 & 9638 & yes \\
\hline Levetin and Dorsey (2006) & Shrub & 5459 & $\mathrm{n} / \mathrm{a}$ & 64363 & 1092 & $\mathrm{n} / \mathrm{a}$ & 12873 & yes \\
\hline Mallo et al. (2010) & Shrub & 285 & $\mathrm{n} / \mathrm{a}$ & 2000 & 57 & $\mathrm{n} / \mathrm{a}$ & 400 & no \\
\hline Mallo et al. (2010) & Shrub & 814 & $\mathrm{n} / \mathrm{a}$ & 3488 & 163 & $\mathrm{n} / \mathrm{a}$ & 698 & no \\
\hline Oliveira et al. (2009) & Shrub & 934 & $\mathrm{n} / \mathrm{a}$ & 8761 & 187 & $\mathrm{n} / \mathrm{a}$ & 1752 & no \\
\hline Rodríguez-Rajo et al. (2005) & Shrub & 950 & $\mathrm{n} / \mathrm{a}$ & $\mathrm{n} / \mathrm{a}$ & 190 & $\mathrm{n} / \mathrm{a}$ & $\mathrm{n} / \mathrm{a}$ & no \\
\hline Rodríguez-Rajo et al. (2005) & Shrub & 979 & $\mathrm{n} / \mathrm{a}$ & $\mathrm{n} / \mathrm{a}$ & 196 & $\mathrm{n} / \mathrm{a}$ & $\mathrm{n} / \mathrm{a}$ & no \\
\hline Sabariego et al. (2000) & Shrub & 832 & $\mathrm{n} / \mathrm{a}$ & $\mathrm{n} / \mathrm{a}$ & 166 & $\mathrm{n} / \mathrm{a}$ & $\mathrm{n} / \mathrm{a}$ & no \\
\hline Sakiyan and Inceoglu (2003) & Shrub & 2917 & 17 & 5817 & 583 & 3 & 1163 & no \\
\hline Gregory (1952) & Crop & 9175 & $\mathrm{n} / \mathrm{a}$ & $\mathrm{n} / \mathrm{a}$ & 1835 & $\mathrm{n} / \mathrm{a}$ & $\mathrm{n} / \mathrm{a}$ & no \\
\hline
\end{tabular}


Table A2. Continued.

\begin{tabular}{|c|c|c|c|c|c|c|c|c|}
\hline Source & Ecosystem & $\begin{array}{l}\text { Average conc. } \\
{\left[\mathrm{m}^{-3}\right]}\end{array}$ & $\begin{array}{l}\text { Min conc. } \\
{\left[\mathrm{m}^{-3}\right]}\end{array}$ & $\begin{array}{l}\text { Max. conc. } \\
{\left[\mathrm{m}^{-3}\right]}\end{array}$ & $\begin{array}{l}\text { Average flux } \\
{\left[\mathrm{m}^{-2} \mathrm{~s}^{-1}\right]}\end{array}$ & $\begin{array}{l}\text { Min flux } \\
{\left[\mathrm{m}^{-2} \mathrm{~s}^{-1}\right]}\end{array}$ & $\begin{array}{l}\text { Max flux } \\
{\left[\mathrm{m}^{-2} \mathrm{~s}^{-1}\right]}\end{array}$ & CFU counts \\
\hline Gregory (1952) & Crop & 11900 & $\mathrm{n} / \mathrm{a}$ & $\mathrm{n} / \mathrm{a}$ & 2380 & $\mathrm{n} / \mathrm{a}$ & $\mathrm{n} / \mathrm{a}$ & no \\
\hline Gregory (1952) & Crop & 6975 & $\mathrm{n} / \mathrm{a}$ & $\mathrm{n} / \mathrm{a}$ & 1395 & $\mathrm{n} / \mathrm{a}$ & $\mathrm{n} / \mathrm{a}$ & no \\
\hline Gregory (1952) & Crop & 9372 & $\mathrm{n} / \mathrm{a}$ & $\mathrm{n} / \mathrm{a}$ & 1874 & $\mathrm{n} / \mathrm{a}$ & $\mathrm{n} / \mathrm{a}$ & no \\
\hline Gregory (1952) & Crop & 13970 & $\mathrm{n} / \mathrm{a}$ & $\mathrm{n} / \mathrm{a}$ & 2794 & $\mathrm{n} / \mathrm{a}$ & $\mathrm{n} / \mathrm{a}$ & no \\
\hline Gregory (1952) & Crop & 9830 & $\mathrm{n} / \mathrm{a}$ & $\mathrm{n} / \mathrm{a}$ & 1966 & $\mathrm{n} / \mathrm{a}$ & $\mathrm{n} / \mathrm{a}$ & no \\
\hline Hamilton (1959) & Crop & 14800 & $\mathrm{n} / \mathrm{a}$ & $\mathrm{n} / \mathrm{a}$ & 2960 & $\mathrm{n} / \mathrm{a}$ & $\mathrm{n} / \mathrm{a}$ & no \\
\hline Hamilton (1959) & Crop & 8200 & 6400 & 10000 & 1640 & 1280 & 2000 & no \\
\hline Wu et al. (2004) & Crop & 28684 & $\mathrm{n} / \mathrm{a}$ & $\mathrm{n} / \mathrm{a}$ & 5737 & $\mathrm{n} / \mathrm{a}$ & $\mathrm{n} / \mathrm{a}$ & no \\
\hline Griffin et al. (2001) & Grassland & 42 & $\mathrm{n} / \mathrm{a}$ & $\mathrm{n} / \mathrm{a}$ & 8 & $\mathrm{n} / \mathrm{a}$ & $\mathrm{n} / \mathrm{a}$ & no \\
\hline Griffin et al. (2003) & Grassland & 24 & $\mathrm{n} / \mathrm{a}$ & $\mathrm{n} / \mathrm{a}$ & 5 & $\mathrm{n} / \mathrm{a}$ & $\mathrm{n} / \mathrm{a}$ & yes \\
\hline Griffin et al. (2003) & Grassland & 46 & 27 & 57 & 9 & 5 & 11 & yes \\
\hline Griffin et al. (2003) & Grassland & 65 & 48 & 90 & 13 & 10 & 18 & yes \\
\hline Griffin et al. (2003) & Grassland & 11 & 8 & 14 & 2 & 3 & 2 & yes \\
\hline Griffin et al. (2007) & Grassland & 869 & $\mathrm{n} / \mathrm{a}$ & $\mathrm{n} / \mathrm{a}$ & 174 & $\mathrm{n} / \mathrm{a}$ & $\mathrm{n} / \mathrm{a}$ & yes \\
\hline Griffin et al. (2007) & Grassland & 215 & 205 & 226 & 43 & 41 & 45 & yes \\
\hline Griffin et al. (2007) & Grassland & 66 & 0 & 703 & 13 & 0 & 141 & yes \\
\hline Griffin et al. (2007) & Grassland & 3 & 0 & 27 & 1 & 0 & 5 & yes \\
\hline Griffin et al. (2007) & Grassland & 1398 & 336 & 6992 & 280 & 67 & 1398 & yes \\
\hline Griffin et al. (2007) & Grassland & 6078 & $\mathrm{n} / \mathrm{a}$ & $\mathrm{n} / \mathrm{a}$ & 1216 & $\mathrm{n} / \mathrm{a}$ & $\mathrm{n} / \mathrm{a}$ & yes \\
\hline Kellogg et al. (2004) & Grassland & 225 & 80 & 370 & 45 & 16 & 74 & yes \\
\hline Kellogg et al. (2004) & Grassland & 65 & 0 & 130 & 13 & 0 & 26 & yes \\
\hline Kellogg and Griffin (2006) & Grassland & 0 & $\mathrm{n} / \mathrm{a}$ & $\mathrm{n} / \mathrm{a}$ & 0 & $\mathrm{n} / \mathrm{a}$ & $\mathrm{n} / \mathrm{a}$ & yes (apart from one source) \\
\hline Kellogg and Griffin (2006) & Grassland & 60 & $\mathrm{n} / \mathrm{a}$ & $\mathrm{n} / \mathrm{a}$ & 12 & $\mathrm{n} / \mathrm{a}$ & $\mathrm{n} / \mathrm{a}$ & yes (apart from one source) \\
\hline Kellogg and Griffin (2006) & Grassland & 6078 & $\mathrm{n} / \mathrm{a}$ & $\mathrm{n} / \mathrm{a}$ & 1216 & $\mathrm{n} / \mathrm{a}$ & $\mathrm{n} / \mathrm{a}$ & yes (apart from one source) \\
\hline Kellogg and Griffin (2006) & Grassland & 4839 & $\mathrm{n} / \mathrm{a}$ & $\mathrm{n} / \mathrm{a}$ & 968 & $\mathrm{n} / \mathrm{a}$ & $\mathrm{n} / \mathrm{a}$ & yes (apart from one source) \\
\hline Prospero et al. (2005) & Grassland & 0 & $\mathrm{n} / \mathrm{a}$ & $\mathrm{n} / \mathrm{a}$ & 0 & $\mathrm{n} / \mathrm{a}$ & $\mathrm{n} / \mathrm{a}$ & yes \\
\hline Wu et al. (2004) & Grassland & $\mathrm{n} / \mathrm{a}$ & $\mathrm{n} / \mathrm{a}$ & 29038 & $\mathrm{n} / \mathrm{a}$ & $\mathrm{n} / \mathrm{a}$ & 5808 & no \\
\hline Pady and Kapica (1955) & Tundra & 30 & 4 & 57 & 6 & 1 & 11 & both methods \\
\hline Pady and Kapica (1955) & Tundra & 87 & 14 & 159 & 17 & 3 & 32 & both methods \\
\hline Pady and Kapica (1955) & Tundra & 3 & 2 & 4 & 1 & 0 & 1 & both methods \\
\hline Pady and Kapica (1955) & Tundra & 39 & 7 & 71 & 8 & 1 & 14 & both methods \\
\hline
\end{tabular}

Acknowledgement. The authors would like to thank Ulrike Lohmann, Ulrich Pöschl, Trude Storelvmo and Nathalie Baumgartner for helpful discussions, Colombe SiegenthalerLeDrian and Tanja Stanelle for expert opinions concerning the boundary layer and emission parameterisation, as well as two anonymous referrees for valuable feedback on this paper.

\section{References}

Abdel-Hafez, S.I.I. and Shoreit, A.A.M.: Mycotoxins producing fungi and mycoflora of air-dust from Taif, Saudi Arabia, Mycopathologia, 92, 65-71, 1985.

Abdel-Hafez, S. I. I., Shoreit, A. A. M., Abdel-Hafez, A. I. I., and E.-Maghraby, O. M. O: Mycoflora and mycotoxin-producing fungi of air-dust particles from Egypt, Mycopathologia, 93(1), 25-32, doi:10.1007/BF00437011,1986.

Abu-Dieyeh, M., Barham, R., Abu-Elteen, K., Al-Rashidi, R., and Shaheen, I.: Seasonal variation of fungal spore populations in the atmosphere of Zarqa area, Jordan, Aerobiologia, 2010.

Amato, P., Ménager, M., Sancelme, M., Laj, P., Mailhot, G., and Delort, A.-M.: Microbial population in cloud water at the Puy de Dôme: Implications for the chemistry of clouds, Atmos. Environ., 39, 4143-4153, 2005.

Amato, P., Parazols, M., Sancelme, M., Laj, P., Mailhot, G., and Delort, A.-M.: Microorganisms isolated from the water phase of tropospheric clouds at the Puy de Dôme: major groups and growth abilities at low temperatures, FEMS Microbiol. Ecol., 59, 242-254, 2007.

Ariya, P., Sun, J., Eltouny, N., Hudson, E., Hayes, C., and Kos, G.: Physical and chemical characterization of bioaerosols - Implications for nucleation processes, Int. Rev. Phys. Chem., 28, 1-32, 2009.

Bauer, H., Kasper-Giebl, A., Löflund, M., giebl, H., Hitzenberger, R., Zibuschka, F., and Puxbaum, H.: The contribution of bacteria and fungal spores to the organic carbon content of cloud water, precipitation and aerosols, Atmos. Res., 64, 109-119, 2002a.

Bauer, H., Kasper-Giebl, A., Zibuschka, F., Hitzenberger, R., Kraus, G., and Puxbaum, H.: Determination of the Carbon Content of Airborne Fungal Spores, Anal. Chem., 74, 91-95, 2002b.

Bauer, H., Claeys, M., Vermeylen, R., Schueller, E., Weinke, G., Berger, A., and Puxbaum, H.: Arabitol and mannitol as tracers for the quantification of airborne fungal spores, Atmos. Environ., 42, 588-593, 2008.

Beaumont, F., Kauffman, H., der Mark, T. V., Sluiter, H., and de Vries, K.: Volumetric Aerobiological Survey of Conidial fungi in the North-East Netherlands, Allergy, 40, 173-180, 1985.

Bhati, H. and Gaur, R.: Studies on Aerobiology - Atmospheric Fungal Spores, New Phytol., 82, 519-527, 1979.

Burch, M. and Levetin, E.: Effects of Meteorological Conditions on Spore Plumes, Int. J. Biometeorol., 46, 107-117, 2002.

Burgess, H.: An update on pollen and fungal spore aerobiology, Journal of Allergy and Clinical Immunology, 110, 544-552, 
2002.

Burkard Scientific: Burkard 7-day volumetric spore sampler, www. burkardscientific.co.uk/agronomics/hirst/spore/sampler.htm, last access: 19 July 2010, 2000.

Côté, V., Kos, G., Martazavi, R., and Ariya, P.: Microbial and "de novo" transformation of dicarboxylic acids by three airborne fungi, Sci. Total Environ., 390, 530-537, 2008.

Davies, R., Denny, M., and Newton, L.: A comparison Between the Summer and Autumn Air-Sporas at London and Liverpool, Acta Allergologica, 18, 131-147, 1963.

DiGiorgio, C., Krempff, A., Guiraud, H., Binder, P., Tiret, C., and Dumenil, G.: Atmospheric Pollution y Airborne Microorganisms in the City of Marseilles, Atmos. Environ., 30, 155-160, 1996.

Elbert, W., Taylor, P. E., Andreae, M. O., and Pöschl, U.: Contribution of fungi to primary biogenic aerosols in the atmosphere: wet and dry discharged spores, carbohydrates, and inorganic ions, Atmos. Chem. Phys., 7, 4569-4588, doi:10.5194/acp-7-4569-2007, 2007.

Fišar, Z., Hýsek, J., and Binek, B.: Quantification of airborne microorganisms and investigation of their interactions with nonlivin particles, Int. J. Biometeorol., 34, 189-193, 1990.

Froehlich-Nowoisky, J., Pickersgill, D., Després, V. R., and Pöschl, U.: High diversity of fungi in air particulate matter, Proceedings of the national academy of science, 106, 12814-12819, doi:10.1073/pnas.0811003106, 2009.

Glikson, M., Rutherford, S., Simpson, R., Mitchell, C., and Yago, A.: Microscopic and Submicron Components of Atmospheric Particulate Matter During High Asthma Periods in Brisbane, Queensland, Australia, Atmos. Environ., 29, 549-562, 1995.

Goncalvez, F. T., Bauer, H., Cardoso, M. R. A., Pukinskas, S., Matos, D., Melhem, M., and Puxbaum, H.: Indoor and outdoor atmospheric fungal spores in the São Paulo metropolitan area (Brazil): species and numeric concentrations, Int. J. Biometeorol., 54, 347-355, 2010.

Gregory, P. H.: Microbiology of the Atmosphere, Leonhard Hill, Aylesbury (Bucks.), chap. 2, 1973.

Gregory, P.: Spore Content of the Atmosphere Near the Ground, Nature, 170, 475-477, 1952.

Gregory, P.: The Dispersal Distance Problem, Pollen Spores, 348, 1962.

Gregory, P.: Atmospheric microbial cloud systems, Scri. Prog. Oxf., 55, 613-628, 1967.

Gregory, P.: Distribution of Airborne Pollen and Spores and their Long Distance Transport, Pure and Applied Geophysics, 116, 309-315, 1978

Griffin, D.: Atmospheric Movement of Microorganisms in Clouds of Desert Dust and Implications ofr Human Health, Climical Microbiology Reviews, 20, 459-477, 2007.

Griffin, D., Garrison, V., Herman, J., and Shinn, E. A.: African desert dust in the Caribbean atmosphere: Microbiology and public health, Aerobiologia, 17, 203-213, 2001.

Griffin, D., Westphal, D., and Gray, M.: Airborne microorganisms in the Aftican desert dust corridor over the mid-Atlantic ridge, Ocean Drilling Program, Leg 209, Aerobiologia, 22, 211-226, 2006.

Griffin, D., Kubliay, N., Koçak, M., Gray, M. A., Borden, T., and Shinn, E.: Airborne deser dust and aeromicrobiology over the Turkish Mediterranean coastline, Atmos. Environ., 41, 40504062, 2007.
Griffin, D. W., Kellogg, C., Garrison, V., Lisle, J., Borden, T., and Shinn, E.: Atmospheric microbiology in the northern Caribbean uring Aftican dust events, Aerobiologia, 19, 143-157, 2003.

Hamilton, E.: Studies on the Air Spora, Acta Allergol., 13, 143$175,1959$.

Harvey, R.: Air-Spora Studies at Cardiff, T. Brit. Mycol. Soc., 50, 479-495, 1967.

Heald, C. and Spracklen, D.: Atmospheric budget of primary biological aerosol particles from fungal spores, Geophys. Res. Lett., 36, L09806, doi:10.1029/2009GL037493, 2009.

Henderson-Begg, S., Hill, T., Thyrhaug, R., Khan, M., and Moffett, B.: Terrestrial and airborne non-bacterial ice nuclei, Atmos. Sci. Lett., 10, 215-219, 2009.

Herrero, A. D., Ruiz, S. S., Bustillo, M. G., and Morales, P. C.: Study of airborne fungal spores in Madrid, Spain, Aerobiologia, 22, 135-142, 2006.

Hirst, J.: An Automatic Volumetric Spore Trap, Ann. Appl. Biol., 39, 257-265, 1952.

Hirst, J.: Changes in Atmospheric Spore Content: Diurnal Periodicity and the Effects of Weather, T. Brit. Mycol. Soc., 36, 375-393, 1953.

Hirst, J. M., Stedman, O., and Hogg, W.: Long-distance Spore Transport: Methods of Mesurement, Vertical Spore Profiles and the Detection of Immigrant Spores, J. Gen. Microbiol., 48, 329355, 1967.

Ho, H., Rao, C., Hsu, H., Chiu, Y., Liu, C., and Chao, H.: Characteristics and determinants of ambient fungal spores in Hualien, Taiwan, Atmos. Environ., 39, 5839-5850, 2005.

Hoose, C., Kristjánsson, J., and Burrows, S.: How important is biological ice nculeation in clouds on a global scale?, Environ. Res. Lett., 5(2), 024009, doi:10.1088/1748-9326/5/2/024009, 2010.

Hyde, K. D., Jones, E. B. G., Leaño, E., Pointing, S. B., Poonyth, A. D., and Vrijmoed, L. L. P.: Role of fungi in marine ecosystems, Biodiversity and Conservation, 7(9), 1147-1161, 1998.

Iannone, R., Chernoff, D. I., Pringle, A., Martin, S. T., and Bertram, A. K.: The ice nucleation ability of one of the most abundant types of fungal spores found in the atmosphere, Atmos. Chem. Phys., 11, 1191-1201, doi:10.5194/acp-11-1191-2011, 2011.

Jacob, D.: Introduction to Atmospheric Chemistry, Princeton University Press, 66-67, 1999.

Jaenicke, R., Matthias-Maser, S., and Gruber, S.: Omnipresence of biological material in the atmosphere, Environ. Chem., 4, 217220, 2007.

Jones, A. and Harrison, R.: The effects of meteorological factors on atmospheric bioaerosol concentrations - a review, Sci. Total Environ., 326, 151-180, 2004.

Kasprzyk, I. and Worek, M.: Airborne fungal spores in urban and rural environments in Poland, Aerobiologia, 22, 169-176, 2006.

Katial, R., Zhang, Y., Jones, R., and Dyer, P.: Atmospheric mold spore counts in relation to meteorological parameters, Int. J. Biometeorol., 41, 17-22, 1997.

Kellogg, C. and Griffin, D.: Aerobiology and the global transport of desert dust, Trends. Ecol. Evol., 21, 638-644, 2006.

Kellogg, C., Griffin, D. W., Garrison, V., Peak, K. K., Royall, N., Smith, R., and Shinn, E.: Characterization of aerosolized bacteria and fungi from desert dust events in Mali, West Africa, Aerobiologia, 20, 99-110, 2004.

Kieft, T.: Ice Nucleation Activity in Lichens, Appl. Env. Microb., 54, 1678-1681, 1988. 
Kieft, T. and Ruscetti, T.: Characterization of Biological Ice Nuclei from a Lichen, J. Bacteriol., 172, 3519-5323, 1990.

Lanzoni: VPPS 2000 sampler, www.lanzoni.it/vpps/2000.html, last access: 19 July 2010, 2010.

Lau, A., Lee, A., Chan, C., and Fang, M.: Ergosterol as a biomarker for the quantification of the fungal biomass in atmospheric aerosols, Atmos. Environ., 40, 249-259, 2006.

Levetin, E.: Bioaerosols, chap. Fungi, CRC Press, Boca Raton, Florida, USA, 1995.

Levetin, E. and Dorsey, K.: Contribution of leaf surface fungi to the air spora, Aerobiologia, 22, 3-12, 2006.

Madelin, T. M.: Fungal Aersols: A Review, J. Aerosol Sci., 25, 1405-1412, 1994.

Mallo, A., Nitiu, D., and Sambeth, M. G.: Airborne fungal spore content in the atmosphere of the city of La Plata, Argentina, Aerobiologia, 2010.

Mandrioli, P.: Basic Aerobiology, Aerobiologia, 14, 89-94, 1998.

Marks, R., Kruczalak, K., Jankowska, K., and Michalska, M.: Bacteria and fungi in air over the Gulf of Gdansk and Baltic season, J. Aerosol Sci., 32, 237-250, 2001.

May, K.: The Cascade Impactor: An Instrument for Sampling Coarse Aerosols, J. Sci. Instrum., 22, 187-195, 1945.

Morris, C. E., Georgakopoulos, D. G., and Sands, D. G.: Ice nucleation active bacteria and their potential role in precipitation, $\mathrm{J}$. Phys. IV, 121, 87-103, 2004.

Oliveira, M., Ribeiro, H., Delgado, J., and Abreu, I.: Seasonal and intradiurnal variation of allergenic fungal spores in urban and rural areas of the North of Portugal, Aerobiologia, 25, 85-98, 2009.

Olson, D., Dinerstein, E., Wikramanayake, E., Burgess, N., Powell, G., Underwood, E., D’Amico, J., Itoua, I., Strand, H. E., Morrison, J., Loucks, C., Allnutt, T. F., ricketts, T., Kura, Y., Lamoureux, J., Wettengel, W. W., Hedeao, P., and Kassem, K.: Terrestrial Ecoregions of the world: A New Map of Life on Earth's, BioScience, 51, 933-938, 2001.

Pady, S.: Quantitative studies of fungus spores in the air, Mycologia, 49, 339-353, 1957.

Pady, S. and Gregory, P.: Numbers and variability of airbore hyphal fragments in England, T. Brit. Mycol. Soc., 46, 609-613, 1963.

Pady, S. and Kapica, L.: Fungi in air over the atlantic oceanic, Mycologia, 47, 34-50, 1955.

Pathak, V. and Pady, S.: Numbers and viability of certain airborne fungus spores, Mycologia, 57, 301-310, 1965.

Pouleur, S., Richard, C., Martin, J.-G., and Antoun, H.: Ice Nucleation Activity in Fusarium acuminatum and Fusarium avenaceum, Appl. Env. Microb., 58, 2960-2964, 1992.

Pratt, K. A., DeMott, P. J., French, J. R., Wang, Z., Westphal, D. L., Heymsfield, A. J., Twohy, C. H., Prenni, A. J., and Prather, K. A.: In situ detection of biological particles in cloud ice-crystals, Nat. Geosci., 2, 397-400, 2009.
Prenni, A. J.: Relative roles of biogenic emissions and Saharan dust as ice nuclei in the Amazon basin, Nat. Geosci., 2, 401-404, 2009.

Prospero, J., Blades, E., Mathison, G., and Naidu, R.: Interhemispheric transport of viable fungi and bacteria from Africa to the Caribean with soil dust, Aerobiologia, 21, 1-19, 2005.

Raddatz, T. J., Reick, C. H., Knorr, W., Kattge, J., Roeckner, E., R., S., Schnitzler, K.-G., Wetzel, P., and Jungclaus, J.: Will the tropical ladn biosphere dominate the climate-carbon cycle feedback during the twenty-first century?, Clim. Dyn., 29, 565-574, 2007.

Rodríguez-Rajo, F., Iglesias, I., and Jato, V.: Variation assessment of airborne Alternaria and Cladosporium spores at different bioclimatical conditions, Mycol. Res., 109, 297-507, 2005.

Sabariego, S., de la Guardia, C. D., and Alba, F.: The effect of meteorological factors on the daily variation of airborne fungal spores in Granada (southern Spain), Int. J. Biometeorol., 44, 1-5, 2000.

Sakiyan, N. and Inceoglu, O.: Atmospheric Concentrations of Cladosporium and Alternaria Spores in Ankara and the Effects of Meteorological Factors, Turk. J. Bot., 27, 77-81, 2003.

Sedlbauer, K. and Krus, M.: Schimmelpilze and Wohngebäuden - Altes Thema, neue Lösungen, in: Proceedings of the Third Dahlberg-Kollogquium "Mikroorganismen und Bauwerkinstandesetzung", Wisman, Germany, 2001.

Simeray, J., Chaumont, J.-P., and Lèger, D.: Seasonal variations in the airborne fungal spore population of the East of France (Franche - Comtè). Comparison between urban and rural environment during two years, Aerobiologia, 9, 201-206, 1993.

Stepalska, D. and Wolek, J.: Intradiurnal periodicity of fungal spore concentration (Alternaria, Botrytis, Cladosporium, Didymella, Ganoderma) in Cracow, Poland, Aerobiologia, 2009.

Winiwarter, W., Bauer, H., Caseiro, A., and Puxbaum, H.: Quantifying emissions of primary biological aerosol particle mass in Europe, Atmos. Environ., 43, 1403-1409, 2009.

World Resource Institute: Eearth Trend Tables: Forests, Grasslands, and Drylands, earthtrends.wri.org/pdf/library/data/tables/ for1/2003.pdf, last access: June 2010, 2003a.

World Resource Institute: Land Area classification by Ecosystem Type, earthtrends.wri.org/pdf/library/data/tables/for1/2003. pdf, last access: June 2010, 2003b.

Wu, P.-C., Tsai, J.-C., Li, F.-C., Lung, S.-C., and Suzuku, H.-J.: Increased levels of ambient fungal spores in Taiwan are associated with dust events from China, Atmos. Environ., 38, 4879-4886, 2004.

Wu, Y., Chan, C., Rao, C., Lee, C.-T., Hsu, H.-H., Chiu, Y.-H., and Chao, H. J.: Characteristics, determinants, and spatial variations of ambient fungal levels in the subtropical Taipei metropolis, Atmos. Environ., 41, 2500-2509, 2007. 